
hypogaea L.) COZIDO COM CASCA ADICIONADO COM AGENTES SABORIZANTES

\author{
CAPÍTULO 07: PREPARACIÓN Y CARACTERIZACIÓN DE CACAHUETE CON \\ CÁSCARA COCIDOS (Arachis hypogaea L.) CON AGENTES AROMATIZANTES
}

\title{
CHAPTER 07: PREPARATION AND CHARACTERIZATION OF COOKED SHELLED PEANUT (Arachis hypogaea L.) WITH FLAVORING AGENTS
}

\author{
Welison Oliveira Santos ${ }^{1}$; Thais Costa Santos ${ }^{1}$; João Paulo Natalino de Sá2 ; Jane Delane Reis Pimentel Souza ${ }^{3}$; \\ Daniel Rodrigues Dutra ${ }^{4}$
}

DOI: https://doi.org/10.31692/978-65-88970-18-8.82-97

\begin{abstract}
RESUMO
Em alguns estados do Brasil, o amendoim (Arachis hypogaea L.) é comercializado cozido na casca, sendo esta forma de consumo muito peculiar no Nordeste do país, com destaque para os estados de Sergipe e da Bahia. Diante disso, o presente estudo teve como objetivo elaborar e caracterizar com relação aos parâmetros físico-químicos ( $\mathrm{pH}$, acidez titulável e umidade), microbiológicos (coliformes termotolerantes) e análise sensorial (teste de aceitação e teste de intenção de compra), o tradicional amendoim cozido com casca em versões saborizadas. Para atingir o objetivo proposto, foram utilizadas duas formulações com a adição de agentes saborizantes durante o cozimento do amendoim com casca em solução aquosa. Os agentes saborizantes utilizados foram o cravo da índia (C), feno grego (FG) e salsão (S), sendo as formulações saborizados denominadas de T1 com $1 \%$ de cravo da índia (C), $1 \%$ de feno grego (FG) e $1 \%$ de salsão (S); formulação T2 com $2 \%$ de cravo da índia (C), $2 \%$ de feno grego (FG) e $2 \%$ de salsão (S), além da formulação controle, ou seja, amendoim cozido com casca em solução com água e sal, denominada de formulação T3. De acordo com os resultados obtidos, foi possível observar que não houve efeito significativo $(\mathrm{p}>0,05)$ entre as formulações de amendoim cozido com a presença de agentes saborizantes (formulações T1 e T2) em relação a formulação controle (T3), para os parâmetros de $\mathrm{pH}$ e umidade. Para a quantificação microbiológica, as formulações T1, T2 e controle (T3), apresentaram valores de coliformes termotolerantes dentro do padrão estabelecido pela legislação vigente. A partir da análise sensorial, foi possível constatar que, pelo teste de aceitação, os atributos avaliados com relação a aparência, textura, sabor e impressão global, não apresentaram diferença significativa $(p>0,05)$ entre as formulações de amendoim cozido com casca com a adição de agentes saborizantes (T1 e T2) e a formulação controle (T3), além disso, todas estas formulações obtiveram boa aceitação sensorial pelos consumidores. Os valores obtidos para a análise de intenção de compra demostraram que as formulações saborizadas ( $\mathrm{T} 1$ e T2), alçaram maiores porcentagens de intenção de compra $(91,0 \%, 93,0 \%$ respectivamente) em comparação a formulação controle (T3) $(88,0 \%)$, demostrando assim, que a utilização de cravo da índia, feno grego e salsão, nas concentrações analisadas, é uma alternativa viável para a elaboração de amendoim cozido saborizado, sendo um produto diferenciado e com potencial mercadológico.
\end{abstract}

Palavras-Chave: ameidoim, cravo da índia, feno grego, salsão..

\section{RESUMEN}

En algunos estados de Brasil, el maní (Arachis hypogaea L.) se vende cocido con cáscara, siendo esta forma de consumo muy peculiar en el Nordeste del país, con énfasis en los estados de Sergipe y Bahía. Ante esto, el presente estudio tuvo como objetivo elaborar y caracterizar con respecto a los parámetros físico-químicos ( $\mathrm{pH}$, acidez titulable y humedad), análisis microbiológico (coliformes termotolerantes) y sensorial (prueba de aceptación y prueba de intención de compra), el tradicional maní cocido con

\footnotetext{
${ }^{1}$ Graduando em Agroindústria, Universidade Federal de Sergipe, welisonsant23@ gmail.com

${ }^{2}$ Doutor, Universidade Federal de Sergipe, jpsadesa@academico.ufs.br

${ }^{3}$ Doutora, Universidade Federal de Sergipe, jdrps@academico.ufs.br

${ }^{4}$ Doutor, Universidade Estadual de São Paulo, dr.dutra@unesp.br
} 
cáscara en versiones aromatizadas. Para lograr el objetivo propuesto, se utilizaron dos formulaciones con la adición de aromatizantes durante la cocción del maní con cáscara en una solución acuosa. Los aromatizantes utilizados fueron el clavo de olor (C), fenogreco (FG) y apio (S), con formulaciones aromatizadas denominadas $\mathrm{T} 1$ con $1 \%$ de clavo de olor (C), $1 \%$ de fenogreco (FG) y $1 \%$ de apio (S); formulación T2 con $2 \%$ de clavo de olor (C), $2 \%$ de fenogreco (FG) y $2 \%$ de apio (S), además de la formulación control, es decir, manís cocidos con cáscara en una solución con agua y sal, denominada formulación T3. De acuerdo con los resultados obtenidos, se pudo observar que no hubo efecto significativo ( $p>0.05)$ entre las formulaciones de maní cocido con la presencia de aromatizantes (formulaciones T1 y T2) en relación a la formulación control (T3), para los parámetros de $\mathrm{pH}$ y humedad. Para la cuantificación microbiológica, las formulaciones T1, T2 y control (T3), presentaron valores de coliformes termotolerantes dentro del estándar establecido por la legislación vigente. A partir del análisis sensorial, se pudo verificar que, mediante la prueba de aceptación, los atributos evaluados en relación a la apariencia, textura, sabor e impresión general, no presentaron diferencia significativa ( $>0.05$ ) entre las formulaciones de maní cocido con presencia de aromatizantes (T1 y T2) y la formulación control (T3), además, todas estas formulaciones obtuvieron una buena aceptación sensorial por parte de los consumidores. Los valores obtenidos para el análisis de intención de compra mostraron que las formulaciones aromatizadas (T1 y T2), obtuvieron mayores porcentajes de intención de compra (91.0\%, 93.0\% respectivamente) en comparación con la formulación control (T3) (88.0\%), demostrando así que el uso de clavo de olor, fenogreco y apio, en las concentraciones analizadas, es una alternativa viable para la elaboración de maní cocido aromatizado, siendo un producto diferenciado con potencial de mercado.

Palabras Clave: Maní, Clavo de olor, Fenogreco, Apio.

\begin{abstract}
In some states in Brazil, peanuts (Arachis hypogaea L.) are sold cooked in their shells, and this form of consumption is particular of the Northeast region of the country, especially on the states of Sergipe and Bahia. In this context, this study aims to elaborate and characterize the physical-chemical parameters $(\mathrm{pH}$, titratable acidity, and humidity), microbiological (thermotolerant coliforms) and sensory analysis (acceptance test and purchase intention test) of traditional cooked peanuts in the shell in flavored versions. To achieve the proposed objective, two formulations were used with the addition of flavoring agents during the cooking of the shelled peanuts in aqueous solution. The flavoring agents used were cloves $(\mathrm{C})$, fenugreek $(\mathrm{FG})$ and celery $(\mathrm{S})$, with flavored formulations called $\mathrm{T} 1$ with $1 \%$ cloves $(\mathrm{C}), 1 \%$ fenugreek (FG), and $1 \%$ celery (S); formulation T2 with $2 \%$ cloves (C), $2 \%$ fenugreek (FG), and $2 \%$ celery (S), in addition to the control formulation, that is, shelled peanuts cooked in a solution with water and salt (T3). The results showed no significant effect $(p>0.05)$ between the formulations of cooked peanuts with the presence of flavoring agents (formulations T1 and T2) in relation to the control formulation (T3), for the $\mathrm{pH}$ and humidity parameters. For microbiological quantification, the formulations T1, T2 and T3, showed values of thermotolerant coliforms within the standard established by current legislation. From the sensory analysis, the attributes evaluated in relation to appearance, texture, flavor and global impression, did not present significant difference $(p>0.05)$ between the formulations of boiled shelled peanuts with the addition of flavoring agents (T1 and T2) and the control formulation (T3). In addition, all formulations received good sensory acceptance scores by the consumers. The values obtained for the purchase intention analysis showed that the flavored formulations (T1 and T2) had higher percentages of purchase intention (91.0\% and 93.0\%, respectively) compared to the control formulation (T3) (88.0\%), thus demonstrating that the use of cloves, fenugreek and celery, in the analyzed concentrations, is a viable alternative for the elaboration of flavored boiled peanuts, being a differentiated product with market potential.
\end{abstract}

Keywords: Peanuts, Cloves, Fenugreek, Celery.

\title{
INTRODUÇÃO
}

Peanuts (Arachis hypogaea L.) are present within the Brazilian population daily diet, either in natura or through their derived products. The states in the Northeast region of Brazil 
are the second largest consumer of peanuts, prevailing the consumption of fresh green peanuts,

being sold in pods in Sergipe and part of Bahia, and as dried peanuts in the rest of that region (BELTRÃO, et al., 2009; BOLONHEZI et al., 2013).

The harvest of green peanuts, sold in pods, has been done between 70 and 75 days. The advantage of this type of cultivation to the farmer is that the crop remains a short time in the soil, taking low risks related to the weather. In the dry peanut market, harvest is conducted between 100 and 110 days and the product is usually sold cooked (20\%) or roasted (80\%), mainly in open markets or processed by the food industries (SANTOS, 1997; VASCONCELOS et al., 2015; BENEDICTI et al., 2018).

The traditional "amendoim sergipano" is characterized by its method of preparation, which occurs, more specifically, by immersing the shelled peanuts in aqueous solution, adding salt and heating them for a few minutes to allow partial cooking of the grains, with subsequent drying.

It is important to note that peanuts are considered a legume with high nutritional and functional value, presenting in their constitution important micro and macronutrients, such as vitamin E, selenium, and polyunsaturated fat (TUCUNDUVA, 2013).

Although peanuts are very popular, new flavored versions can further increase the sales and commercialization of the traditional "amendoim sergipano", potentializing the demand for new markets.

\section{THEORETICAL FUNDAMENTATION}

\section{General aspects of peanuts}

Peanut is a plant belonging to the Fabaceae family and genus Arachis, with dicotyledonous, herbaceous and annual characteristics, in which Arachis hypogea L. stands out as the most important among cultivated species. Among the three species, Valencia and Virgnia types are more commercially cultivated in Brazil (SANTOS et al., 1997; SILVA, et al. 2010). It is a plant from South America that was introduced in Europe in the 17th century. In the 19th century, peanuts spread from Brazil to Africa and from Peru to the Philippines, China, Japan and India, being known and appreciated in almost all of these countries (SUASSUNA et al., 2006).

The peanut plant has great genetic plasticity, being able to be cultivated under various environmental conditions (FIROUZI et al., 2009) and in almost all types of soils, being the best 
production found in those with good drainage, moderate fertility, and sandy texture. The highest profitability is due to the cultivar and to interactions between temperature and water availability (BOLONHEZI et al., 2013). Moreover, this crop constitutes an excellent agricultural alternative for the Northeast region of Brazil, due to the nutritional richness of its seeds and the adaptation to semi-arid conditions (FREITAS et al., 2005).

Peanut is one of the most produced oilseeds worldwide, occupying the fourth place in the world ranking, getting behind only to the cultivation of soy, cotton and rapeseed (canola) (FREITAS et al., 2005). In Brazil, there are at least 80 species, and although it is a widely exploited culture in the Southeast, in the Northeast it is still little cultivated due to the lack of knowledge and investments to implant this culture, among other factors (SANTOS et al., 2012).

Brazilian peanut production consists of two crops sown at different times, depending on the region of cultivation, the first is sown in the South and Southeast, whereas the second is sown in the North, Northeast and Midwest. The largest producer is the state of São Paulo, being responsible for about $80 \%$ of national production (SANTOS et al., 2006; CONAB, 2019).

Although the Northeast region is the second largest consumer of peanuts in Brazil, its production serves only $28 \%$ of regional demand, intensified during "Festas Juninas". The main producing regions are the "Agreste" of the states of Paraíba, Sergipe, and Bahia and the semiarid region in "Cariri cearense". In these regions, peanut cultivation is mainly conducted by family farmers and small and medium producers in small areas (AMENDOIM BR1, 2016).

Cultivation of peanuts shows relevant economic importance in Brazil, since their production is related to the fact that their seeds can be processed and used directly on human food, canning industry, confectioneries, oleochemical industries and production of biodiesel (BOLONHEZI et al., 2013).

\section{Nutritional aspects of peanuts}

Peanut is known and appreciated for its characteristic flavor and its use on savory and sweet dishes within the industry. Peanut fruit presents high concentrations of oil, proteins and vitamins, being an important source of energy and amino acids for human food (FIROUZI et al., 2009). Overall, peanuts are composed of approximately $70 \%$ of grains or seeds and $30 \%$ of husks. Among the several species of peanuts, Arachis hypogaea L. is the only one that has been domesticated and widely cultivated (ARAUJO, et al., 2014).

When compared to other oilseeds, peanuts have advantages, once they contain higher protein content and lower lipid content in their composition, in addition to a high oleic acid 
content, the main MUFA (from 38 to $60 \%$ of its lipid content) corresponding to 20-30g per 100

$\mathrm{g}$ of peanuts in grain or paste (BRODNJAK-VONCINA et al., 2004; SALES et al., 2005; MACIEL, 2018).

Peanuts, due to the characteristics of the grain, have an important role to the global feeding. Its oil is superior in quality than olive oil, which might help to prevent cardiovascular diseases. In addition, the grains have high concentrations of vitamin E, important antioxidant that can reduce the risks of getting cancer, diabetes and autoimmune diseases, with high concentrations of selenium and polyunsaturated fat (FRANCISCO and RESURRECCION, 2008; TUCUNDUVA, 2013).

Since the peanut provides satiety, low energy absorption and increased energy expenditure after consumption, it does not contribute significantly to increase body weight despite its high lipid content. Improved nutrient profiles in the diet and low body mass index (BMI) were associated with the consumption of peanuts (GRIEL et al., 2004; MATTES; KRISETHERTON; FOSTER, 2008; MACIEL, 2018). For those reasons, peanut has been included in the list of foods with several health benefits. Even with high energy value, it has high nutritional value and high percentage of fibers. Regarding socioeconomic aspects, peanuts, due to their various forms of consumption and processing, can contribute to increasing family income, adding income for medium and small farmers, especially for those living in the Northeast region (TUCUNDUVA, 2013).

\section{Market}

Worldwide, peanuts are popular, being one of the most consumed snacks in the world. The market of this food generates around US\$18.5 billion a year. The biggest consumers of peanuts are the European Union, Japan, Russia, Indonesia, Canada and Mexico. The largest exporters are Argentina, China, India, Nigeria, United States, which occupies the main position as producers and consumers in the world (CONAB, 2019). The Brazilian peanut production is relatively moderate, domestic consumption shows significant indexes, close to the mark of 100 thousand tons of peanuts per year, presenting a growing demand for this food recently (AGRIANUAL, 2016; CONAB, 2019).

Peanut production in the Brazilian Northeast is intended for fresh consumption, consisting of cooked and roasted peanuts, distributed through open markets. In addition, in large northeastern cities, especially the coastal ones, peanuts are sold by street sellers who errand in the city's bars and restaurants carrying their manual carts, which keep the product warm, with 
great acceptability among consumers (AYDIN, 2007; BALASUBRAMANIAN et al., 2011).

This legume has significant importance in the nutrition and agricultural sustainability of arid and semi-arid regions of Brazil, being cultivated by medium and small producers, through family farming, requiring low mechanization and few inputs. In these regions, where climatic adversities are significant, peanuts represent a viable agricultural alternative due to their easy handling, short cycle and receptive market (LEAL, 2019).

Peanuts are, therefore, related to playful and recreational consumption, which integrates individual and collective urban daily practices (DUTRA, 2012). In some states of Brazil, such as Sergipe and Bahia, peanuts have become a popular food, handcrafting planted, produced and sold, involving the local culture, with a singular taste appreciated by multiple social groups and many tourists who visit those areas.

\section{Celery (Apium graveolens L.)}

Celery is a vegetable classified as herbaceous, whose usable parts are above the ground, making it tender and juicy, being used as food; whereas plant and seeds, both are consumed as medicines (BEVILACQUA, 2006; MOMIN and NAIR, 2002).

It originates from Europe and the Mediterranean, it has essential oils, calcium, vitamins (A, B1, B2, B5, C, E), iron, magnesium and sodium chloride. Although originated in Europe, its consumption became popular in Brazil due to its antioxidant, carminative, digestive, refreshing, tonic and anti-inflammatory activity, due to the presence of aliin, allicin, thiophene derivatives and sulfur compounds in its composition (MARTINS, 2000; BIASI, 2010; BENEDICTI et al., 2018).

In Brazil, celery consumption is low, probably due to the lack of knowledge of consumers about its nutritional qualities and easy preparation (TAVARES; LANA, 2016).

\section{Clove (Syzygium aromaticum)}

Clove (Syzygium aromaticum) is a species belonging to the family Myrtaceae, known for having high amounts of essential oils. Its tree can vary from 8 to $12 \mathrm{~m}$, has a large, ovalshaped leaves and its red flowers appear in numerous groups of terminal clusters (TIWARI, 2009; COUTINHO et al., 2020).

Largest producers of cloves are Indonesia, India and Madagascar (HAIDA, 2007). In 
Brazil, the outstanding cultivation of cloves is located in the state of Bahia, in Valença, Ituberá, and Camumu cities (OLIVEIRA et al., 2009; CÓRTES-ROJAS et al., 2014).

Researchers have been reporting that cloves have several pharmacological benefits, such as antiviral, antidiabetic, anesthetic, anti-inflammatory (AFFONSO et al., 2012) and antimicrobial activities (ALMEIDA et al., 2013; MOON et al., 2011, COUTINHO et al., 2020), in addition to its potential as non-synthetic preservative in food matrices, with differentiated flavors and odors.

\section{Fenugreek (Trigonella Foenum-Graecum)}

Fenugreek T. foenum graecum (Linnaeus, 1758) is a vegetable that belongs to the legume family, genus Trigonella, which has its name derived from the ancient Greek, referring to 'three angles', probably due to the triangular shape of the flowers (MEYER, 2019; VIEIRA, 2019).

It is a plant originally from India and North Africa, but is currently cultivated in Egypt, Morocco, Argentina, France, China, Chile and the United States. In semi-arid regions of North America, is considered a high-yield niche culture (HEUZÉ et al., 2018; SAXENA et al., 2012)

Seeds and green leaves of fenugreek have been used in food preparations and medicinal applications for more than 2500 years. Nowadays, studies aiming to know the possible benefits of fenugreek on human health are being conducted (AWAD et al., 2015; BAHI et al., 2017).

In addition, new studies have reported that this vegetable has antioxidant action due to its considerable concentration in polyphenols, flavonoids, phenolic acids, coumarins, saponins (such as diosgenin and yamogenine), alkaloids (such as trimethylamine, neurin, trigonelline, etc.), tannins and carotenoids (SAXENA et al., 2011; VIEIRA, 2019).

\section{METHODOLOGY}

\section{Obtaining shelled peanuts}

Shelled peanuts (Arachis hypogaea L.) were harvested 75 days after planting in a production field located in the county of Ribeirópolis - SE and Arapiraca - AL. Peanuts were transported on the same day of harvest, in previously cleaned containers, to the laboratory to proceed with the processing and analyses. The flavoring agents (cloves, fenugreek and celery) were purchased in markets located in Nossa Senhora da Glória - SE. 


\section{Processing}

Peanut processing was conducted as shown in Figure 1, following the steps of selection, washing; cooking; drainage, drying and storage, for further physical-chemical, microbiological, and sensory analysis.

Figure 01. Detailed flowchart for obtaining peanuts.

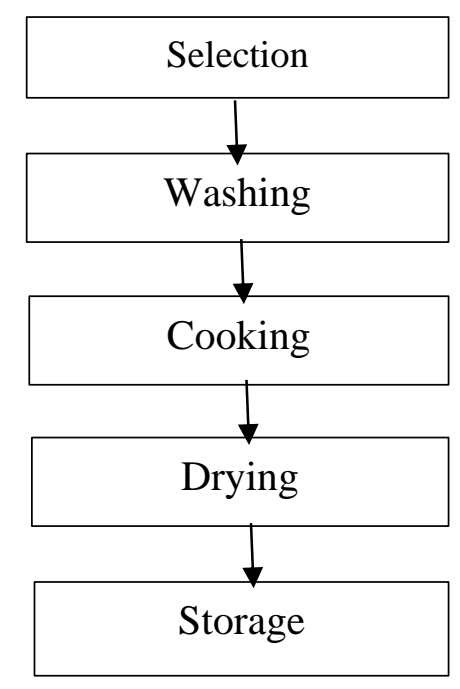

Source: Own authorship

The selection stage eliminated impurities such as leaves, soil, straw and pods with injuries; then the peanut pods (shell) were washed with potable water to eliminate possible remaining dirt. After this stage, the shelled peanuts were cooked in an industrial pan for $40 \mathrm{~min}$, at approximately $100^{\circ} \mathrm{C}$. During this stage, salt (50 g/L) was added to the aqueous solution for all formulations (T1, T2, and T3) and flavoring agent for formulations T1 with 1\% cloves (CL), $1 \%$ fenugreek (FG), and $1 \%$ celery (CE) and formulation T2 with $2 \%$ cloves (CL), $2 \%$ fenugreek $(\mathrm{FG})$, and $2 \%$ celery $(\mathrm{CE})$. The concentrations of flavoring agents were based on results obtained in previous acceptance tests. Lastly, the peanuts were placed in previously cleaned plastic pots and stored under refrigeration $\left(8^{\circ} \mathrm{C} \pm 2^{\circ} \mathrm{C}\right)$ for $24 \mathrm{~h}$ for further physicalchemical, microbiological and sensory analysis.

\section{Physicochemical analysis}

Quantification of contents of $\mathrm{pH}$, acidity and humidity of all treatments of cooked shelled peanuts were conducted in triplicate according to the standards of the Instituto Adolfo 
pH

Quantification of $\mathrm{pH}$ was performed by weighing 3 grams of each sample separately; then, the samples were immersed in distilled water. To determine the $\mathrm{pH}$ of the samples, a potentiometer model AF 401, MS (Tecnopon, Brazil) previously calibrated with standard solutions of $\mathrm{pH} 4.0$ and 7.0 was used, according to the standards of IAL (2008).

\section{Total titratable acidity}

Determination of total acidity was performed by titration with a standardized solution of $\mathrm{NaOH} 0.1 \mathrm{~mol} / \mathrm{L}$ using phenolphthalein as an indicator. Results were expressed as a percentage of lactic acid (IAL, 2008).

\section{Moisture content}

Determination of moisture content was conducted by gravimetric method in an oven at $105^{\circ} \mathrm{C}$ (Huanghua Faithful Instrument Co., WHL 25AB, China), until constant weight, according to the standards of IAL (2008). About $3 \mathrm{~g}$ of each sample was weighed in a previously tared crucible and taken to the oven. Lastly, the samples were removed, cooled in a desiccator and weighed until a constant weight was obtained. The results were expressed as percentages.

\section{Microbiological analysis}

Formulations of cooked shelled peanuts, with the addition of flavored agents (T1 and T2) and formulation of cooked shelled peanuts with no addition of flavorings (T3) were submitted to the quantification of thermotolerant coliforms using the most probable number (MPN) technique, initially cultivated in a water bath at a temperature of $36^{\circ} \mathrm{C}$ for $48 \mathrm{~h}$ in two subsequent assays with Lauril Sulfato Triptose (LST) and then with Brilliant Green (BV), for presumptive and confirmatory tests, respectively, for each sample. BV-positive tubes were streaked in Escherichia coli broth (EC), then incubated in a water bath at $45^{\circ} \mathrm{C}$ for $48 \mathrm{~h}$ for analysis of thermotolerant coliforms. Results were expressed in MPN/g. 
Sensory analysis (sensory acceptance and purchase intention) was conducted with 72 untrained judges, without gender definition, by using the hedonic scale of nine points for the attributes: visual appearance, texture, flavor and overall impression. Hedonic scale ranged from 1 (extremely disliked) to 9 (extremely liked). A five-point scale, ranging from 1 (certainly would not buy) to 5 (certainly would buy), was used for the purchase intention test.

\section{Statistical analysis}

Data obtained from physical-chemical and sensory analysis, were evaluated using Analysis of Variance (ANOVA) and Tukey test, at 5\% of significance, through the software Statística 7.0. Microbiological results were analyzed based on qualitative and quantitative description, in comparison to the current legislation.

\section{RESULTS AND DISCUSSION}

\section{Physico-chemical characterization}

Table 01 presents the physical-chemical parameters of different formulations of flavored cooked peanuts and control formulation related to $\mathrm{pH}$, acidity and moisture content.

Table 01. Averages of physico-chemical analysis of $\mathrm{pH}$, acidity and humidity for different formulations of cooked peanuts.

\begin{tabular}{cccc}
\hline Formulation & pH & Acidity (\%) & Moisture content $(\%)$ \\
\hline T1 & $5.96^{\mathrm{a}} \pm 0.12$ & $6.2^{\mathrm{a}} \pm 0.12$ & $44.43^{\mathrm{a}} \pm 1.35$ \\
T2 & $5.94^{\mathrm{a}} \pm 0.02$ & $5.4^{\mathrm{b}} \pm 0.09$ & $43.33^{\mathrm{a}} \pm 3.70$ \\
T3 & $5.89^{\mathrm{a}} \pm 0.03$ & $6.5^{\mathrm{a}} \pm 0.05$ & $43.01^{\mathrm{a}} \pm 5.01$ \\
\hline
\end{tabular}

Source: Own authorship

Averages followed by the same letter in a column do not differ by Tukey's Test $(>0.05)$. T1 (1\% Clove, $1 \%$ Fenugreek, $1 \%$ Celery); T2 (2\% CL, 2\% FG, 2\% C); T3 (control) (0\% CL, 0\% FG, 0\% CE).

Based on the presented results, it was possible to identify that there were no significant differences $(p>0.05)$ in relation to the $\mathrm{pH}$ parameter for the analyzed formulations, regardless the presence or absence of flavoring agents. Cooked peanut formulations showed $\mathrm{pH}$ values ranging from $5.89 \pm 0.03$ (T3) to $5.96 \pm 0.12$ (T2). These values were lower than those found in a research conducted by Batista (2010), who reported a $\mathrm{pH}$ close to $6.81 \pm 0.01$ for raw 
peanuts with no shell. These $\mathrm{pH}$ value differences found for cooked peanuts may have occurred

due to the addition of salt, which favored the salt unbalance, possibly, leading to a pronounced acidity in the samples analyzed. The potential of hydrogen $(\mathrm{pH})$ analysis contributes to the determination of different reactions in a food matrix, for example, in microbial multiplication and in the speed of the activity of different enzymes, in addition, the knowledge of the $\mathrm{pH}$ value in a given food matrix might assist on choosing the type of packaging, aiming to control, for example, the diffusion of food flavor and sent to the external environment (CECCHI, 2003).

The titratable acidity analysis showed a significant difference $(p<0.05)$ between formulations with $1 \%$ flavoring (T1) and formulation with $2 \%$ flavoring, being observed higher acidity value for this formulation compared to the formulation without flavorings (T3, control) and to the formulation with $1 \%$ flavoring agents (T2) (Table 07). Higher concentration of flavorings in the $\mathrm{T} 2$ formulation may have favored a pronounced acidity in this sample compared to the other formulations (control and T1). Within the flavorings used in formulations T1 and T2, the cloves, which is mainly composed of eugenic acid (SHIN et al. 2009), might have possibly favored the increase in acidity in formulation 2 (T2), which contained $2 \%$ cloves, since no significant difference was observed $(p>0.05)$ between formulation without flavoring agents (T3, control) and the formulation with addition of $1 \%$ cloves (T1).

Regarding the moisture analysis, it was possible to verify that there was no difference $(p>0.05)$ between flavored and control formulations (water and salt). Moisture values found, regardless of the type of formulation, showed relatively higher values, compared to the moisture value found in the study of Rodrigues et al. (2011), who reported an index of approximately $3.00 \%$ moisture for raw peanuts. The higher moisture value found in peanuts in our research is mainly due to the type of processing, since it was cooked submerged in an aqueous solution, which probably favored greater diffusion of solvent into the peanut pod, resulting in humidity values higher than that found in the literature. Although higher humidity values in peanuts may favor the multiplication of undesirable microorganisms (ELIAS, 2008; KRICHENE et al., $2010)$, the storage temperature of peanuts after cooking, under refrigeration $\left(8.0^{\circ} \mathrm{C} \pm 2.0^{\circ} \mathrm{C}\right)$ is an important tool to control the speed of microbial multiplication (LEE and RESURRECCION, 2006), reason why all the analyzed samples were stored under refrigeration temperature $\left(8.0^{\circ} \mathrm{C}\right.$ $\pm 2.0^{\circ} \mathrm{C}$ ) after processing,

\section{Microbiological analysis}

Quantification of thermotolerant coliforms for different formulations of flavored cooked 
Table 02.

Table 02 - Quantification of thermotolerant coliforms in samples of cooked shelled peanuts with the addition of

\begin{tabular}{ccc}
\multicolumn{2}{c}{ flavored agents (T1 and T2) and control sample (peanuts cooked with water and salt) } \\
\hline Formulation & Thermotolerant coliforms (MPN/g) & Legislation standard \\
\hline \multicolumn{2}{c}{ T1 } & $2,3 \times 10^{1}$ \\
T2 & $<1,0 \times 10^{1^{*}}$ & maximum of $10^{3}$ \\
T3 & $1,1 \times 10^{2}$ & \\
\hline
\end{tabular}

Source: Own authorship

T1 (1\% Clove, $1 \%$ Fenugreek, $1 \%$ Celery); T2 (2\% CL, 2\% FG, 2\% CE); T3 (control) (0\% CL, 0\% FG, 0\% CE); *: estimated value.

According to the results obtained, it was possible to affirm that all formulations analyzed met the requirements of the current Brazilian regulations, which recommends, according to Resolution - RDC n⿳ 12, of January 2, 2001 (ANVISA), the maximum value of $103 \mathrm{MPN} / \mathrm{g}$ of thermotolerant coliforms in peanuts (BRASIL, 2001). The results found are similar to the values found by Spinelli (2018), that observed that all analyzed peanut samples from the public market of Porto Alegre in Rio Grande do Sul, ranged into the limits established by the current legislation.

The analysis of thermotolerant coliforms is an important parameter to evaluate the sanitary hygienic conditions established during the production process (JAY, 2005). Given the found result, it is possible to state that these conditions were satisfactory during all processing stages of the formulations analyzed.

\section{Sensory analysis}

In Table 03, it is possible to verify the results obtained in relation to the attributes analyzed for sensory acceptance and purchase intention for different formulations of cooked shelled peanuts.

Table 03. Averages of sensory acceptance of samples for different formulations of cooked shelled peanuts with presence and absence of flavoring agents

\begin{tabular}{|c|c|c|c|c|}
\hline Formulation & $\begin{array}{c}\text { Visual } \\
\text { Apperance }^{1} \\
\end{array}$ & Texture $^{1}$ & Flavor $^{1}$ & $\begin{array}{c}\text { Overall } \\
\text { Impression }^{1}\end{array}$ \\
\hline $\mathrm{T} 1$ & $6.43^{\mathrm{a}} \pm 1.85$ & $6.97 \mathrm{a} \pm 1.59$ & $7.22^{\mathrm{a}} \pm 1.72$ & $6.80^{\mathrm{a}} \pm 1.77$ \\
\hline $\mathrm{T} 2$ & $6.83^{\mathrm{a}} \pm 1.64$ & $7.34^{\mathrm{a}} \pm 1.35$ & $7.12^{\mathrm{a}} \pm 1.72$ & $7.11^{\mathrm{a}} \pm 1.49$ \\
\hline T3 (Control) & $6.66^{\mathrm{a}} \pm 1.53$ & $7.25^{\mathrm{a}} \pm 1.63$ & $7.12^{a} \pm 1.72$ & $7.06^{\mathrm{a}} \pm 1.47$ \\
\hline
\end{tabular}


$1 \%$ Celery); T2 (2\% CL, $2 \%$ FG, $2 \%$ CE); T3 (control) ( $0 \%$ CL, $0 \%$ FG, $0 \%$ CE). ${ }^{1} 1$ - "I extremally disliked" to 9 - "I extremely liked". ${ }^{2} 1$ - "I certainly wouldn't buy" to 5 - "I certainly would buy".

The results show no significant difference $(\boldsymbol{p}>0.05)$ between different formulations, considering the acceptance test for the attributes: visual appearance, texture, flavor and overall impression, thus demonstrating that addition of flavoring agents in the studied concentrations did not have negative influence on the analyzed attributes. The results regarding the purchase intention can be seen in Figure 02.

Figure 02. Purchase intention for peanut shelled samples cooked with the addition of flavoring agents (t1 and $\mathrm{t} 2$ ) and control sample with water and salt (t3).

\section{Buy intention}
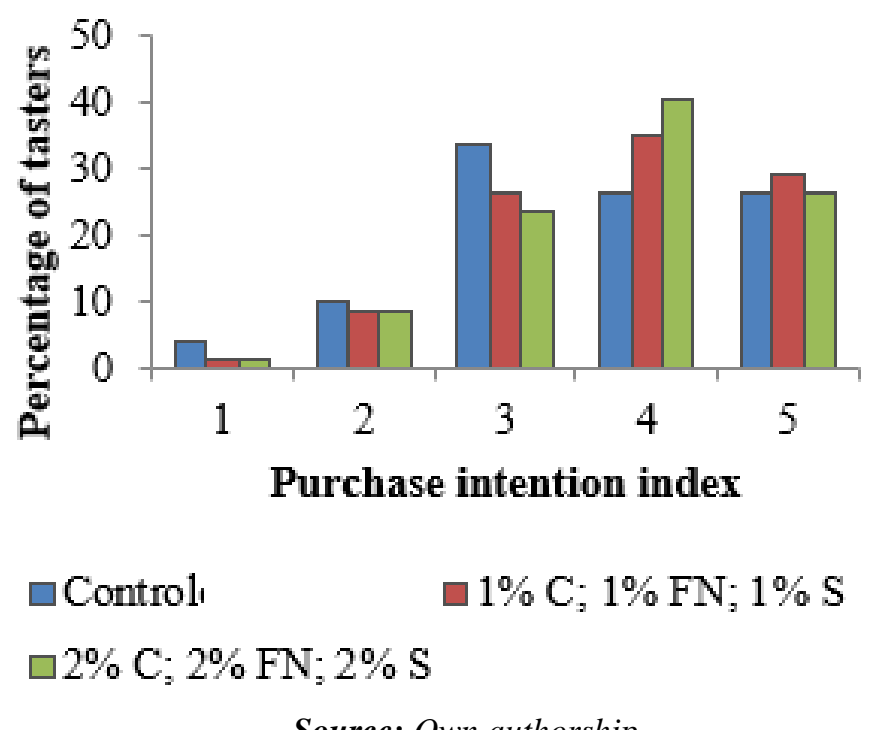

Source: Own authorship

Figure 02 infers that the highest averages of purchase intention were observed between scores 4 (would probably buy) and 5 (certainly would buy), with higher prevalence of purchase intention for samples of cooked shelled peanuts added with flavoring agents (T1 and T2), in relation to the control sample, that is, peanuts cooked only with water and salt. These results demonstrate that the use of flavoring agents such as cloves, fenugreek and celery in concentrations of 1 and $2 \%$ in cooked peanuts, can be an alternative for new versions of this food matrix.

\section{CONCLUSION}

From the results obtained, it was possible to verify that the addition of clove, fenugreek 
and celery as flavoring agents in concentrations of $1 \%$ and $2 \%$ in shelled peanuts during the

cooking stage, does not negatively affect the physical-chemical, microbiological, and sensorial parameters of cooked shelled peanuts, thus demonstrating that addition of flavorings under the concentrations studied in this food matrix, can be a viable and differentiated alternative for new versions of this product.

\section{REFERENCES}

AMENDOIM BR1. 6. ed. Campina Grande: Embrapa Algodão, 2016. 1 Fôlder

BELTRÃO, N. E. M.; SANTOS, R. C.; GONDIM, T. M. S.; NOGUEIRA, R. J. M. C.; MELO FILHO, P. A. Ecofisiologia e manejo cultural. In: SANTOS, R. C.; FREIRE, R. M. M.; SUASSUNA, T. M. F. (Org.). Amendoim: o produtor pergunta, a Embrapa responde. Brasília, DF: Embrapa Informação Tecnológica, 2009. v. 1, p. 15-38

BENEDICTI, C. M; SANTOS, L. R.; DROVAL, A. A. Utilização de Aipo em pó (Aipium graveolens) no processamento de linguiça toscana. Brazilian Journal of Food Research, Campo Mourão, v. 9 n. 1, p. 25-40, jan./mar. 2018.

BIASI, V. Produção de salame tipo Italiano através de cura natural com extrato de aipo e acelga. 2010. 141 f. Dissertação (Mestrado em Ciência e Tecnologia dos Alimentos) Programa de Pós-Graduação em Ciência e Tecnologia dos Alimentos, Universidade Federal de Santa Maria, 2010.

BOLONHEZI, D.; GODOY, I. J.; SANTOS, R. C. Manejo cultural do amendoim. In: SANTOS, R. C.; FREIRE, R. M. M.; LIMA, L. M. O agronegócio do amendoim no Brasil. Brasília, DF: Embrapa, 2013. p. 185-237.

CECCHI, H. M. Fundamentos teóricos e práticos em análises de alimentos. 2. ed. Campinas: Unicamp, 2003.

CONAB (Brasil). Acompanhamento da Safra Brasileira de Grãos, v. 6 - safra 2018/19 Sétimo levantamento. Brasília, DF, 2019. p. 1-69.

DUTRA, A. F. Eficiência agroeconômica do consórcio mamona e amendoim em área do Semiárido paraibano. 2012. 85 f. Dissertação (Mestrado em Ciências Agrárias) Universidade Estadual da Paraíba, Centro de Ciências Humanas e Agrárias, Campina Grande.

ELIAS, M. C. Manejo tecnológico da secagem e do armazenamento de grãos. Pelotas: Santa Cruz, p. 362, 2008.

KRICHENE, D.; ALLALOUT, A.; MANCEBO-CAMPOS, V.; SALVADOR, M. D.; ZARROUK, M.; FREGAPANE, G. Stability of virgin olive oil and behavior of its natural antioxidants under medium temperature accelerated storage conditions. Food Chemistry. London: v. 121, n. 1, p.171-177, 2010. 
INSTITUTO ADOLFO LUTZ. Métodos físico-químicos para análise de alimentos. São Paulo: Instituto Adolfo Lutz, 2008. 1000p.

JAY, J. M. 2005. Microbiologia de Alimentos. 6. ed. Porto Alegre: Artmed, 712p

LEE, C. M.; RESURRECCION, A. V. A. Consumer acceptance of roasted peanuts affected by storage temperature and humidity conditions. Food Science and Technology, v.39, p.872$882,2006$.

MARTINS, D. I.; MIDIO, A. F. Toxicologia dos alimentos. 2 Ed. São Paulo: Varela, 2000. MEYER C., ed. Dicionário de Ciências Animais. 2019. [Online], França: CIRAD. Disponível em: http://dico-sciences-animales.cirad.fr/. Acesso em: 03 abr. 2021.

MEXIS, S.F.; BADEKA, A.V.; KONTOMINAS, M.G. Quality evaluation of raw ground almond kernels (Prunus dulcis): Effect of active and modified atmosphere packaging, container oxygen barrier and storage conditions. Innovative Food Science and Emerging Technologies, Ioannina: v. 10, p. 580-589, 2009.

RODRIGUES, A.C.; STRÖHER, G.L.; FREITAS, A.R.; VISENTAINER, J.V.; OLIVEIRA, C.C.; SOUZA, N.E. The effect of genotype and roasting on the fatty acid composition of peanuts. Food Research International, v. 44, p. 187-192, 2011

SANTOS, R. C. dos; GONDIM, T. M.; SILVA, A. F. S.; ARRIEL, N. H. C., P. de A.; SILVA FILHO, J. L. Manejo do amendoim rasteiro no nordeste brasileiro. Petrolina, 2012b. (Circular técnica, 98).

SAXENA, S. N. et al. Analysis of antioxidant activity, phenolic and flavanoids content of fenugreek (Trigonellafoenum graecum L.) seed extracts. Int J Seed Spices, v. 1, n. 1, p. 3843, 2011.

SPINELLI, L.; LONGONI, L.; SILVEIRA, A. B. Análise microbiológica de amostras de amendoim provenientes do mercado público de Porto Alegre/RS. Revista de Ciências Ambientais, v. 12, n. 2, p. 39-49, 2018.

UEMURA, T. et al. Diosgenin, the main aglycon of fenugreek, inhibits LXR $\alpha$ activity in HepG2 cells and decreases plasma and hepatic triglycerides in obese diabetic mice. The Journal of nutrition, v. 141, n. 1, p. 17-23, 2010.

VASCONCELOS, F. M. T.; VASCONCELOS, R. A.; LUZ, L. N.; CABRAL, N. T.; OLIVEIRA JUNIOR, J. O. L.; SANTIAGO, A. D.; SGRILLO, E.; FARIAS, F. J. C.; MELO FILHO, P. A.; SANTOS, R. C. Adaptabilidade e estabilidade de genótipos eretos de amendoim cultivados nas regiões Nordeste e Centro-Oeste. Ciência Rural, v. 45, n. 8, p .1375-1380, 2015. DOI: $10.1590 / 0103-8478 \mathrm{cr} 20140414$.

VIEIRA, N. S. Semente de feno grego (trigonella foenum graecum) na alimentação de tilápia do nilo: avaliação in vivo da capacidade imunoestimulante e promotora de crescimento e atividade antioxidante no filé. Trabalho de conclusão de curso. Bacharelado em Zootecnia, da Universidade Tecnológica Federal do Paraná, campus Dois Vizinhos, como 
